\title{
QMRAcatch: Human-Associated Fecal Pollution and Infection Risk Modeling for a River/Floodplain Environment
}

\author{
Julia Derx, Jack Schijven, Regina Sommer, Christa M. Zoufal-Hruza, Inge H. van Driezum, Georg Reischer, Simone Ixenmaier, \\ Alexander Kirschner, Christina Frick, Ana Maria de Roda Husman, Andreas H. Farnleitner, and Alfred Paul Blaschke*
}

\begin{abstract}
Protection of drinking water resources requires addressing all relevant fecal pollution sources in the considered catchment. A freely available simulation tool, QMRAcatch, was recently developed to simulate concentrations of fecal indicators, a genetic microbial source tracking (MST) marker, and intestinal pathogens in water resources and to conduct a quantitative microbial risk assessment (QMRA). At the same time, QMRAcatch was successfully applied to a region of the Danube River in Austria, focusing on municipal wastewater emissions. Herein, we describe extension of its application to a Danube River floodplain, keeping the focus on fecal sources of human origin. QMRAcatch was calibrated to match measured human-associated MST marker concentrations for a dry year and a wet year. Appropriate performance characteristics of the human-associated MST assay were proven by simulating correct and false-positive marker concentrations, as determined in human and animal feces. With the calibrated tool, simulated and measured enterovirus concentrations in the rivers were compared. Finally, the calibrated tool allowed demonstrating that $4.5 \log _{10}$ enterovirus and $6.6 \log _{10}$ norovirus reductions must be achieved to convert current surface water to safe drinking water that complies with a health-based target of $10^{-4}$ infections person ${ }^{-1} \mathrm{yr}^{-1}$. Simulations of the low- and high-pollution scenarios showed that the required viral reductions ranged from 0 to $8 \log _{10}$. This study has implications for water managers with interests in assessing robust catchment protection measures and water treatment criteria by considering the fate of fecal pollution from its sources to the point of abstraction.
\end{abstract}

\section{Core Ideas}

- QMRAcatch is a fecal pollution and infection risk model for water resources.

- QMRAcatch was successfully applied to a river/floodplain environment.

- Successful calibration was shown using human-associated HF183 MST marker data.

- Sustainable viral reduction targets to achieve safe drinking water quality were estimated.

- Results show a high potential for targeting human emissions in the catchment.

Copyright $\odot$ American Society of Agronomy, Crop Science Society of America, and Soil Science Society of America. 5585 Guilford Rd., Madison, WI 53711 USA.

All rights reserved.

J. Environ. Qual. 45:1205-1214 (2016)

doi:10.2134/jeq2015.11.0560

This is an open access article distributed under the terms of the CC BY-NC-ND

license (http://creativecommons.org/licenses/by-nc-nd/4.0/).

Supplemental material is available online for this article.

Received 11 Nov. 2015.

Accepted 21 Mar. 2016.

*Corresponding author (blaschke@hydro.tuwien.ac.at).
S USTAINABLE PROTECTION OF WATER RESOURCES is a major policy goal worldwide. In recent years, the catchment-to-tap principle has been introduced, and it considers all possible sources of fecal pollution: within the watershed, at the water abstraction, during distribution, and at consumption (WHO, 2011). Inspired by the European Water Framework Directive (EU, 2006) and the Rotorua Declaration (HRWM, 2011), the microbial water quality model QMRAcatch was recently developed (Schijven et al., 2015). QMRAcatch is a completely mixed reactor type model with first-order degradation in a main river with point wastewater discharges, a floodplain river, and a floodplain area with diffuse fecal sources. The main river feeds the floodplain river during flood events. The model structure includes the fate and transport of target microbes and viruses (TMVs), including common fecal indicator bacteria, genetic microbial source tracking (MST) markers, and selected intestinal pathogens originating from wastewater treatment plant (WWTP) sources and from animals or visitors into the main river and the floodplain river. The TMV concentrations in the different reactors are calculated by generating 365 random Monte Carlo samples for each day of a year. Degradation is considered dependent on travel time and water temperature using degradation rates derived from literature data. River travel times are calculated for this purpose using the Manning-GaucklerStrickler formula (Manning, 1891). For computing the TMVs

J. Derx, I.H. van Driezum, and A.P. Blaschke, TU Wien, Institute of Hydraulic Engineering and Water Resources Management, E222/2, Karlsplatz 13, A-1040 Vienna, Austria; J. Derx, Regina Sommer, I.H. van Driezum, G. Reischer, S. Ixenmaier, A. Kirschner, A.H. Farnleitner, and A.P. Blaschke, Interuniversity Cooperation Centre for Water and Health (ICC Water \& Health); J. Derx, I.H. van Driezum, and A.P. Blaschke, TU Wien, Centre for Water Resource Systems, E222/2, Karlsplatz, 13 A-1040 Vienna, Austria; J. Schijven and A.M. de Roda Husman, National Institute for Public Health and the Environment (RIVM), Expert Centre for Methodology and Information Services, PO Box 1, 3720 BA Bilthoven, The Netherlands; J. Schijven, Utrecht Univ., Faculty of Geosciences, Dep. of Hydrogeology, Utrecht, The Netherlands; R. Sommer and A. Kirschner, Medical Univ. of Vienna, Institute for Hygiene and Applied Immunology of the Center for Pathophysiology, Infectiology and Immunology, Kinderspitalgasse 15, 1090 Vienna, Austria; C.M. Zoufal-Hruza and C. Frick, Vienna Municipal Dep. 39, Laboratories of Environmental Medicine, Feldgasse 9, A-1080 Vienna, Austria; G. Reischer, S. Ixenmaier, and A.H. Farnleitner, TU Wien, Institute of Chemical Engineering, Research Group Environmental Microbiology and Molecular Ecology, Gumpendorferstraße 1a, 1060 Vienna, Austria; A.M. de Roda Husman, Utrecht Univ., Faculty of Veterinary Medicine, Institute for Risk Assessment Sciences, Utrecht, The Netherlands. Assigned to Associate Editor Thomas Harter.

Abbreviations: $C_{\text {hum }}$, concentration in human feces; DSW, Danube River observation sites; LSW, floodplain area and floodplain river observation sites; MPN, most probable number; MST, microbial source tracking; $P_{\text {hum }}$, probability of visitors practicing open defecation; $\mathrm{PI}$, point of interest; QMRA, quantitative microbial risk assessment; RBF, river bank filtration; TMVs, target microbes and viruses; WWTP, wastewater treatment plant. 
in the floodplain river, the dilution with a fraction of river water volume is considered only if the river flow discharge at a certain day exceeds a certain threshold level. In the floodplain, the following lumped processes are included in the model structure: fecal deposits from wildlife, birds, and visitors in the floodplain that are resuspended in flood water, runoff to the floodplain river, and/or groundwater infiltration. Target microbes and viruses contained in fecal droplets can be transported into the floodplain river, depending on the daily amount of rainfall and lumped release, runoff, and die-off rates. The model structure and assumptions of QMRAcatch are described in detail by Schijven et al. (2015). Infection risks from exposure to the pathogenic TMVs by swimming or consuming drinking water are calculated based on dose-response models, and the required pathogen reduction (i.e., removal and inactivation) to meet a health-based target for water quality or waterborne disease can be determined.

Recently, QMRAcatch was calibrated to simulated concentrations of the standard fecal indicator Escherichia coli and the human-associated genetic fecal MST marker HF183 in the Danube River in Austria to predict enterovirus concentrations (Schijven et al., 2015), but it was not done for the river/floodplain environment.

Several modeling studies exist on the environmental fate and transport of fecal indicator organisms from various sources, including urban runoff, sewer discharges, wildlife, and agricultural nonpoint source pollutants (Benham et al., 2006; Chin et al., 2009; Wu et al., 2009). Models on a catchment scale were also developed based on the multi-criteria method (Cool et al., 2010) or on climate data (Schijven et al., 2013). Recent work includes the application of water flow and microbial water quality models combined with quantitative microbial risk assessment (QMRA) (McBride et al., 2012; Sokolova et al., 2015). A microbial water quality model that is calibrated on the basis of indicators can be used to simulate pathogen concentrations that are often below the achievable limit of detection. In the Danube river, the predominant source of fecal pollution is from communal and domestic wastewater emission sources (Schijven et al., 2015). These pollution sources can reach the floodplain river during floods. Along the floodplain river, animals also contribute to fecal pollution (Vierheilig et al., 2013), and fecal droppings from boar, deer, and birds were frequently spotted along the floodplain river during the investigation period. In contrast to E. coli, which occurs in both animal and human fecal excrement (e.g., Farnleitner et al., 2010), human-associated MST marker concentrations support source-targeted calibration of the communal and domestic wastewater emission sources. Therefore, we evaluated the application of a human-associated genetic fecal MST marker. The contribution of this paper is that the model performance was tested by comparing simulated genetic MST marker and pathogen concentrations in the Danube River and the floodplain river with observation data for a dry year and a wet year (Anonymous, 2014). This is in contrast to McBride et al. (2012) and Sokolova et al. (2015), who focused on the source concentration and used hydrodynamic models to convey the contaminants to points of exposure. A further contribution of this paper is that the calibrated and tested model allowed simulating various pollution scenarios for the selected pathogens based on assumed or measured values within the considered catchment.
The first objective of the work was to extend the application of QMRAcatch to a river/floodplain environment on the Danube River for potential human fecal sources, which was already implemented in the model structure (Schijven et al., 2015). In addition, the applicability of a human-associated genetic MST marker for model calibration was evaluated. For this purpose, catchment-specific quantitative fecal sensitivity (i.e., correctpositive MST marker concentrations from human sources) and specificity (i.e., false-positive MST marker concentrations from animal sources) characteristics of the selected human-associated MST qPCR assay were incorporated into the modeling effort. The second objective was to compare high- and low-pollution case scenarios based on the calibrated model to estimate sustainable reduction targets of selected viral pathogens for robust water safety management in the considered catchment. Enterovirus and norovirus were selected as human pathogenic viruses that cause serious and frequent disease in humans, respectively. This study has implications for water managers with interests in assessing robust catchment protection measures and water treatment criteria by considering the fate of fecal pollution from its sources to the point of abstraction and the required treatment.

\section{Materials and Methods}

\section{Site Description for the Case Study}

The study site, located at the Danube River in Vienna, Austria, included a floodplain area and a floodplain river with observation points 1, 2, 3, and 4 (LSW 1-4; Fig. 1). The model domain included five WWTPs upstream of the point of interest (PI) where the floodplain river connects to the Danube River (see Table 1 for upstream distances). As a national park, the flood plain area is important for preservation of nature and recreation. It is a Natura 2000 protected area and, as such, is home

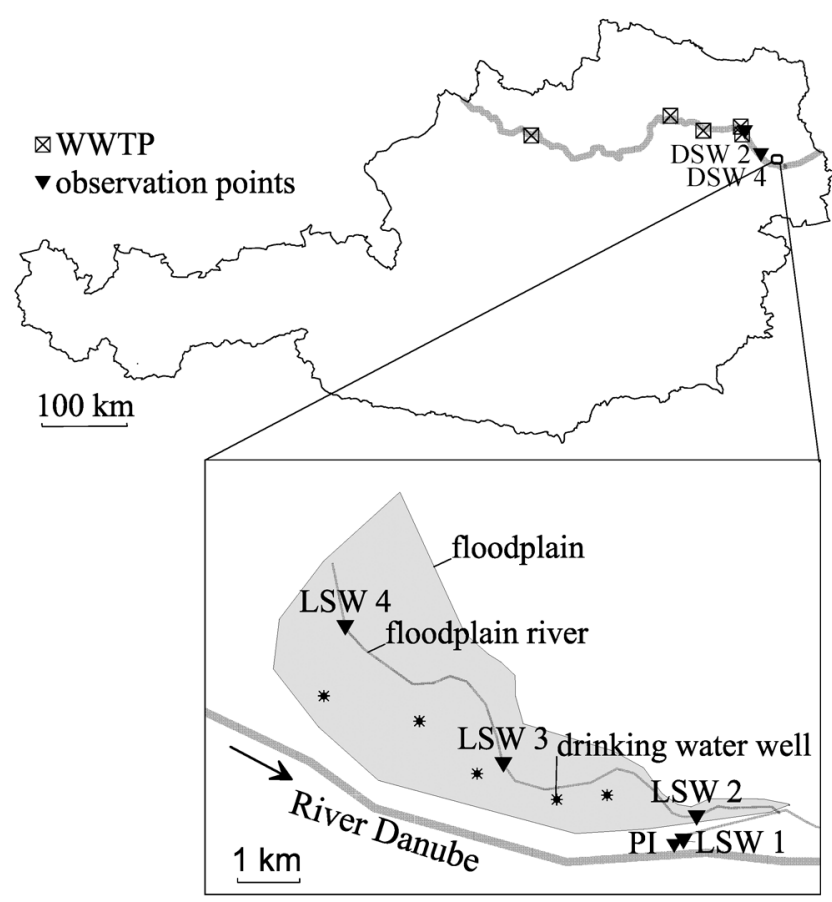

Fig. 1. Bird's-eye view of the floodplain area of the Danube River, Austria. The locations of the wastewater treatment plants (WWTPs), observation points, and drinking water wells are shown. DSW, Danube river observation sites; LSW, floodplain river observation sites. 


\begin{tabular}{|c|c|c|c|c|}
\hline Parameter & Unit & Description & Default value & Reference \\
\hline \multicolumn{5}{|c|}{ Concentration of TMVs in raw wastewater; calibration WWTP $2+3$} \\
\hline \multirow[t]{3}{*}{ Mean } & $\mathrm{N} \mathrm{L}^{-1}$ & enterovirus & $(8.1,10) \times 10^{2}$ & Schijven et al. (2015), WHO (2011) \\
\hline & & norovirus & $10^{5}$ & Katayama et al. (2008) \\
\hline & & HF183 & $(1.8,1.0) \times 10^{9}$ & Schijven et al. (2015) \\
\hline \multirow[t]{3}{*}{ 95th percentile } & $\times$ mean & all TMVs & 2 & \\
\hline & $N^{-1}$ & enterovirus & $(2.5,2.8) \times 10^{3}$ & \\
\hline & & HF183 & $(5.8,3.5) \times 10^{9}$ & \\
\hline \multicolumn{5}{|c|}{ Concentration of TMVsł in storm water overflow, multiplication factor of TMV concentration in raw wastewater } \\
\hline \multirow[t]{2}{*}{ Mean and 95th percentile } & - & 2012 & $0.1 \S$ & This paper \\
\hline & & 2013 & $0.4 \S$ & \\
\hline \multicolumn{5}{|c|}{ Log reduction by wastewater treatment } \\
\hline \multirow[t]{3}{*}{ Mean } & $\log _{10}$ & enterovirus & 1.2 & Schijven et al. (2015), Lodder and de \\
\hline & & norovirus & 1 & Roda Husman (2005) \\
\hline & & HF183 & $2.8,2.2$ & Schijven et al. (2015) \\
\hline \multirow[t]{3}{*}{ 95th percentile } & $\times$ mean & all TMV & 0.75 & \\
\hline & $\log _{10}$ & enterovirus & $0.4 \S$ & \\
\hline & & HF183 & $1.9,1.4 \S$ & \\
\hline \multicolumn{5}{|l|}{ Characteristics of WWTP $1-5$} \\
\hline Upstream distance & $\mathrm{km}$ & & $20,24,43,77,193$ & \\
\hline Discharge & $\mathrm{m}^{3} \mathrm{~s}^{-1}$ & & $0.1,0.1,0.1,0.2,2.2$ & WWTP authorities \\
\hline Overflow & $\mathrm{Nyr}^{-1}$ & & $3 \S$ & This paper \\
\hline Mixing degree & - & & $0.6,0.65,0.7,0.75,0.8$ & \\
\hline \multicolumn{5}{|c|}{ Fecal droppings of boar/red deer } \\
\hline \multirow[t]{4}{*}{ Population } & $\mathrm{N} \mathrm{d}^{-1}$ & boar & 150 & Arnberger et al. (2009), Vierheilig et \\
\hline & & red deer & 240 & al. (2013), Arnberger (2006), Eder and \\
\hline & & visitors & 900 & \\
\hline & & birds & 900 & Parz-Gollner (2006) \\
\hline \multirow[t]{2}{*}{ Mean weight } & $\mathrm{g}$ & boar & 10 & Schmidt et al. (2004) \\
\hline & & red deer & 15 & von Oheimb et al. (2005) \\
\hline 95th percentile of weight & $\times$ mean & & 2 & \\
\hline \multirow[t]{2}{*}{ Number } & $d^{-1}$ animal $^{-1}$ & boar & 5 & Schmidt et al. (2004) \\
\hline & & red deer & 15 & von Oheimb et al. (2005) \\
\hline Mean TMV concentrations & $\mathrm{Ng}^{-1}$ & HF183 (nontargets) & $10^{3}$ & Farnleitner et al. (2014) \\
\hline $95 \%$ & $\times$ mean & all TMVs & 2 & \\
\hline \multicolumn{5}{|l|}{ Fecal droppings of birds } \\
\hline Mean weight & $g$ & & 0.5 & Hahn et al. (2007) \\
\hline 95th percentile of weight & $\times$ mean & & 2 & \\
\hline Number & $d^{-1}$ bird $^{-1}$ & & 50 & Hahn et al. (2007) \\
\hline Mean TMV concentrations & $\mathrm{Ng}^{-1}$ & HF183 (nontargets) & $10^{3}$ & Farnleitner et al. (2014) \\
\hline 95th percentile & $\times$ mean & all TMVs & 2 & \\
\hline \multicolumn{5}{|l|}{ Fecal droppings of humans } \\
\hline \multirow[t]{2}{*}{ Weight } & $g$ & mean & 150 & Encyclopedia Brittanica (2015) \\
\hline & $\times$ mean & $95 \%$ & 2 & \\
\hline \multirow[t]{2}{*}{ Probability } & - & & $2012: 0.02 \S$ & This paper \\
\hline & & & 2013:0.01§ & \\
\hline \multirow[t]{4}{*}{ Mean TMV concentrations } & $\mathrm{Ng}^{-1}$ & enterovirus & $10^{5}$ & Melnick and Rennick (1980) \\
\hline & & norovirus & $10^{5}$ & Atmar et al. (2008) \\
\hline & & HF183 & $2012: 5 \times 10^{7}$ & Farnleitner et al. (2014) \\
\hline & & & $2013: 3 \times 10^{7}$ & \\
\hline 95th percentile & $\times$ mean & all TMVs & 2 & \\
\hline Prevalence & - & enterovirus & 0.01 & \\
\hline & & norovirus & 0.01 & \\
\hline Main river & & & & \\
\hline Discharge, $Q_{\mathrm{mr}}$ & $\mathrm{m}^{3} \mathrm{~s}^{-1}$ & & data from spreadsheet & \\
\hline Width & $\mathrm{m}$ & & 250 & \\
\hline Depth & $\mathrm{m}$ & & 4 & \\
\hline
\end{tabular}




\begin{tabular}{|c|c|c|c|c|}
\hline Parameter & Unit & Description & Default value & Reference \\
\hline \multicolumn{5}{|l|}{ Floodplain river } \\
\hline Discharge, $Q_{\mathrm{fr}}$ ? & $\mathrm{m}^{3} \mathrm{~s}^{-1}$ & fraction of $Q_{\mathrm{mr}}$ & polynomial regression & This paper (Supplemental Fig. S1) \\
\hline Length & $\mathrm{km}$ & & 50 & \\
\hline Width & $\mathrm{m}$ & & 0.5 & \\
\hline Depth & $\mathrm{m}$ & & 0.5 & \\
\hline \multicolumn{5}{|l|}{ Main river and floodplain river } \\
\hline Manning coefficient & $\mathrm{s} \mathrm{m}^{-0.3}$ & & river: 0.024 , floodplain river: 0.035 & Manning (1891) \\
\hline River bed slope & $\mathrm{m} \mathrm{m}^{-1}$ & & river: 0.0004 , floodplain river: 0.001 & Schulze et al. (2005), via donau (1997) \\
\hline Water temperature & ${ }^{\circ} \mathrm{C}$ & & data from spreadsheet & \\
\hline \multicolumn{5}{|l|}{ Floodplain } \\
\hline Precipitation & $\mathrm{mm}$ & & data from spreadsheet & \\
\hline Floodplain angle & degrees & & 1 & \\
\hline Floodplain area & $\mathrm{km}^{2}$ & & 50 & \\
\hline Release from fecal deposits & $1 d^{-1}$ & & 2012: $0.006,2013: 0.5 \S$ & This paper \\
\hline Evaporation/precipitation & - & & 0.4 & Merz and Blöschl (2009) \\
\hline Runoff coefficient & - & & 0.1 & \\
\hline
\end{tabular}

† The concentrations of target microorganisms and viruses in raw wastewater and the calibration to wastewater treatment plant (WWTP) 2 and 3 are shown in Table 1 in Schijven et al. (2015).

¥ Target microbes and viruses.

$\S$ From calibration.

I Includes groundwater recharge.

to a variety of birds, deer, and boar, among other wildlife. The floodplain river is currently connected to the Danube River if the water level of the Danube is higher than the annual mean water level. On average, the floodplain is partially flooded once every year. The aquifer in the floodplain is also used as a drinking water resource.

\section{Evaluating the Applicability of the Human-Associated Microbial Source Tracking Marker to Calibrate the Model}

During monitoring of the floodplain site, animal fecal droppings were regularly spotted along the floodplain river. Because the focus of this work was on human fecal pollution, a humanassociated MST marker was selected as a genetic fecal indicator, as determined by the HF183 TaqMan assay (Green et al., 2014). Although the markers found by the HF183 TaqMan assay (HF183) are primarily associated with human feces and sewage, low numbers may also occur in animal feces. A total of 18 human, 16 boar, 18 deer, and 16 bird feces samples were collected from the studied floodplain area in 2004, 2005, 2010, and 2011 and were analyzed for the HF183 MST marker (Farnleitner et al., 2014). The HF183 MST marker concentrations in human feces $\left(C_{\text {hum }}\right)$ were derived from selected wastewater discharges and human fecal droppings in the investigated catchment. The HF183 MST marker $C_{\text {hum }}$ averaged $6 \times 10^{7}$ marker equivalents per gram $\left(\mathrm{me} \mathrm{g}^{-1}\right)$, and the 5 th and 95 th percentiles were $1 \times$ $10^{\circ}$ and $1 \times 10^{8} \mathrm{me} \mathrm{g}^{-1}$, respectively (Farnleitner et al., 2014). The HF183 MST marker concentrations were also determined in deer, boar, and bird feces, averaging $1 \times 10^{3} \mathrm{me}^{-1}$; the fifth and 95th percentiles were $1 \times 10^{\circ}$ and $1 \times 10^{4} \mathrm{me} \mathrm{g}^{-1}$, respectively (Farnleitner et al., 2014), indicating that concentrations in animal feces are about four orders of magnitude lower than those in human feces. Nevertheless, the impact on false-positive HF183 MST marker detection rates in the floodplain may become significant, such as when a large animal population is the source. The impact on the simulated HF183 MST marker concentrations from animal sources in the floodplain river was therefore investigated with QMRAcatch. The model variables, which are the HF183 MST marker concentrations in boar, deer, and bird feces, were varied within the measured ranges.

\section{Pollution Source Targeted Calibration and Verification of QMRAcatch}

Calibration of QMRAcatch targeting the human fecal pollution sources within the selected catchment was performed stepwise, and then the calibrated model was verified by comparing measured and simulated enterovirus concentrations. The stepwise calibration was performed manually as follows:

1. In Schijven et al. (2015), we described the settings of concentrations in raw wastewater and reduction of the HF183 MST marker and enterovirus concentrations in the five WWTPs upstream on the basis of measured concentrations of the HF183 MST marker and enterovirus in raw and treated wastewater. All model variables were either taken from daily measured data or from the literature (Table 1).

2. QMRAcatch was set to match simulated with measured HF183 MST marker concentrations in the Danube River for the year 2012. The HF183 MST marker concentrations in the Danube River were measured at the PI $(n=11$ for 2012; $n=8$ for 2013) (Fig. 1). Data for mean daily river discharges, river and floodplain river water temperatures, and precipitation were available from 2012 to 2013 . The mean daily discharges from the floodplain river and the flooded area were estimated by means of regression because no rating curve was available. Polynomial functions (using MS Excel 2010) were fitted to observed hourly river discharges and to flow simulations of a calibrated 2-D hydrodynamic surface water model (CCHE-2D; Univ. of Mississippi-National Center for Computational Hydroscience and Engineering, 
Supplemental Fig. S1) (Gabriel et al., 2014). The HF183 MST marker concentrations in the Danube River were calibrated by adjusting the mixing degrees and number of overflows per year until the mean, 95th percentiles, and shape parameters ( $\alpha$ and $\beta$ ) of the gamma distributions of the simulated and the observed concentrations over one year, matched. The HF183 MST marker concentrations in overflow water were also adjusted using a fixed ratio of raw influent concentrations in WWTPs that was varied from 1 to 5 .

3. QMRAcatch was then set to match simulated with measured HF183 MST marker concentrations in the floodplain river for 2012. HF183 MST marker concentrations in the floodplain river were measured at locations LSW 1,2,3, and $4(n=11$ for $2012 ; n=6$ for 2013$)$. The probability of visitors practicing open defecation $\left(P_{\text {hum }}\right)$ and the release rate were adjusted. The release rate is the fraction of deposited numbers of HF183 MST markers in the floodplain released daily. The HF183 MST marker $C_{\text {hum }}$ were further adjusted within the previously measured range (Farnleitner et al., 2014). The HF183 MST marker concentrations in bird, deer, and boar feces were set to the mean measured values (Table 1 ).

4. Steps 2 and 3 were repeated using river discharge and precipitation data from 2013. The adjusted parameters were kept the same for both years except for HF183 MST marker concentrations in overflow water and release rates because these are influenced by rainfall events. These parameters were therefore adjusted independently for each year.

5. Verification was performed by comparing simulated and measured enterovirus concentrations in the Danube River for 2012 and 2013 and in the floodplain river for 2013 using the same settings found in Steps 2, 3, and 4. This comparison is needed to evaluate the applicability of the HF183 MST marker to set QMRAcatch variables for predicting virus concentrations Enterovirus concentrations in the Danube River were measured at the observation points 2 and 4 ( $n=11$ for 2012; $n=5$ for 2013) (DSW 2 and 4; Fig. 1) and in the floodplain river at location LSW $3(n=6)$.

The human-associated HF183 MST marker concentrations were determined by the TaqMan assay according to the procedure described by Green et al. (2014) with modifications for sample processing and DNA extraction described by Reischer et al. (2008). Isolation of virus particles was performed according to the procedure described by Walter and Rüdiger (1981) and enumerated as described by Chang et al. (1958).

\section{Required $\log _{10}$ Reduction of Viral Pathogens to Achieve Drinking Water Quality}

A primary objective was to evaluate QMRAcatch as a tool to study the impact of environmental changes or changes in management strategies on the concentrations of human pathogenic enterovirus and norovirus in surface water and how these changes affect the required $\log _{10}$ reduction of enterovirus and norovirus from surface water to achieve drinking water quality. Four scenarios were defined by changing groups of model variables that are likely to be affected in the future. The groups were defined for when low pollution is experienced in a wet year, when high pollution is experienced in a wet year, when low pollution is experienced in a dry year, and when high pollution is experienced in a dry year. In addition, the current situation was investigated for a dry year and a wet year with the calibrated model. Variables selected to describe the extent of human fecal pollution included amount of reduction by wastewater treatment, ranging from zero to high; number of visitors; prevalence; and $P_{\text {hum }}$, ranging from low to high (Table 2). The low pollution scenario was characterized by a low number of visitors contributing to human fecal pollution and a low $P_{\text {hum }}$ in the floodplain area. The number of visitors was taken from the reported numbers of visitors, excluding bikers and visitors from the surrounding area (Arnberger, 2006; Eder and Arnberger, 2012). The high pollution scenario was characterized by a high number of visitors and a high $P_{\text {hum }}$ in the floodplain area.

Variables were further varied reflecting hydrologic and climatic changes. The years 2003 and 2002 were selected because the lowest and highest mean annual discharges from the Danube River since 1996 were recorded in these years (Anonymous, 2014). In the simulations, the precipitation amounts and discharges from the Danube River and the floodplain river were taken from observational data collected during these years. The runoff coefficient was set to 0.1 , and the ratio of evaporation to precipitation was set to 0.4. According to Merz and Blöschl (2009), the mean event runoff coefficients range from 0.1 to 0.4 , and the ratio of evaporation to precipitation ranges from 0.4 to 0.9 in the region where the study area was located. Accordingly, the model variables in the simulations were assumed to be within these ranges constantly over time (Table 1). Air and water temperatures are likely to increase in the future by a few degrees Celsius (Blöschl et al., 2011). From the calibration procedure, however, it became evident that the runoff coefficient, evaporation, and water temperatures affect the simulated viral concentrations in the floodplain river relatively little compared with model variables that are associated with fecal pollution (not shown). This is because their possible ranges are small in comparison with those of the latter. The viral release rate from feces is, as such, influenced by the amount and intensity of rainfall. This model variable was adjusted for an extremely dry year and an extremely wet year during the calibration (2012 and 2013, respectively). In the scenarios for the wet and dry years, the release rate was therefore varied accordingly (Table 2). Different mixing ratios of Danube River water, floodplain river water, and floodplain water at the drinking water well were also assumed for the dry and the wet years, according to Taschke et al. (2014) (Table 2). All other variables were those of the "calibrated" model or were taken from the literature (concentrations of enterovirus and norovirus in raw wastewater and feces, wastewater discharges and upstream distance, dropping weight, overflows and overflow water concentrations of enterovirus and norovirus, mixing degrees, river lengths and widths, Manning coefficients and slopes of the river beds, floodplain slopes, release rates, evaporation, and runoff) (Table 1).

Simulated enterovirus and norovirus concentrations in the Danube River, in the floodplain river, and in the floodplain were compared between scenarios. For each scenario, the required $\log _{10}$ reductions necessary to achieve drinking water quality from the Danube River and the floodplain river that complies with the health target of $10^{-4}$ person ${ }^{-1} \mathrm{yr}^{-1}$ were calculated. The dose response model for norovirus and enterovirus is the hypergeometric dose response model (details given by Schijven et al. [2015]). It accounts for beta-distributed infectivity levels of the viruses and for Poisson-distributed virus particle numbers for the 
dose estimation. For waterborne viruses it is assumed that virus particles at low concentrations in water samples can be statistically described by the Poisson distribution (i.e., virus particles are assumed to be randomly distributed in the water sample). For enteroviruses, the dose response relationship is associated with the enumeration of infectious virus particles, as enumerated in the tissue culture. In the case of norovirus, the dose response model was developed on the basis of PCR enumeration, which includes noninfectious virus particles (Teunis et al., 2008). In all scenarios, the number of Monte Carlo samples was set to $10^{6}$, calculations with QMRAcatch were repeated 10 times, and the average concentrations and $\log _{10}$ reductions were calculated.

\section{Results}

\section{Applicability of the Human-Associated Microbial Source Tracking Marker for Model Calibration}

When varying the reported false-positive marker concentration in animal feces for the HF183 qPCR assay, the simulated HF183 MST marker concentrations in the floodplain river varied by only 5 to $8 \%$, meaning that 92 to $95 \%$ of all possible variations were associated with human pollution sources in the catchment according to the QMRAcatch simulations. The HF183 qPCR assay and the measured concentrations thus proved to be useful for human source-targeted model calibration for the given situation.

\section{Model Calibration and Verification}

The simulated and observed HF183 MST marker and enterovirus concentrations and cumulative distribution functions at the PIs in the Danube River and in the floodplain river are presented in Supplemental Fig. S2 and S3. Simulated mean, 95th percentiles, and gamma distribution parameters $\alpha$ and $\beta$ of HF183 MST marker concentrations at the PI in the Danube River in 2012 and 2013 differed by less than $0.4 \log _{10}$ from the respective measured values (Table 3). The HF183 MST marker concentrations in overflow water were adjusted independently for each year because they may vary. For example, uptake from urban surface runoff during heavy rainfall events can cause larger concentrations in overflow water than during dry years. The factor between HF183 MST marker concentrations in overflow water and HF183 MST marker concentrations in raw wastewater was 0.1 in 2012 and 0.4 in 2013 (Table 1). Extremely severe rainfall events occurred in 2013, whereas 2012 was characterized by extremely dry periods (total precipitation was 510 and 660 $\mathrm{mm}$ in 2012 and 2013, respectively). Higher concentrations in overflow water in 2013 than in 2012 therefore seem justified. The maximum difference between the mean, 95th percentiles, and gamma distribution parameters $\alpha$ and $\beta$ of simulated and measured concentrations of enterovirus was $0.6 \log _{10}$ in 2012 (Table 3). In 2013, enterovirus was not detected three out of five times; therefore, only the mean and 95 th percentiles of simulated and measured concentrations could be compared, and the absolute difference was no less than $0.1 \log _{10}$.

Simulated and measured mean, 95th percentiles, and gamma distribution parameters $\alpha$ and $\beta$ of HF183 MST marker concentrations in the floodplain river were less than $0.3 \log _{10}$ (Table 3). Values for $P_{\text {hum }}, C_{\text {hum }}$, and the HF183 MST marker 
release rate were adjusted. In 2012 and $2013, P_{\text {hum }}$ was 0.02 and 0.01 , respectively; $C_{\text {hum }}$ was $5 \times 10^{7} \mathrm{me} \mathrm{g}^{-1}$ and $3 \times 10^{7} \mathrm{me} \mathrm{g}^{-1}$, respectively; and the release rates were 0.006 and $0.5 \mathrm{~d}^{-1}$, respectively (Table 1). Values for $P_{\text {hum }}$ and $C_{\text {hum }}$ varied little across the years because they are not influenced by changes in climatic or hydrological conditions. The release rate was set much lower in 2012 than in 2013 , consistent with the extremely dry conditions in 2012 and the extremely wet conditions in 2013. The absolute biases of the mean, 95th percentiles, gamma distribution parameters $\alpha$ and $\beta$, and simulated and observed HF183 MST marker concentrations in the floodplain river were $0.3 \log _{10}$. The observed enterovirus concentrations in the floodplain river were consistently below the detection limit of $0.1 \mathrm{MPN}$ (most probable number) $\mathrm{L}^{-1}$. The mean and 95th percentiles of the simulated enterovirus concentrations in the floodplain river were 0.05 and $0.09 \mathrm{MPN} \mathrm{L}^{-1}$, respectively, and were therefore below the detection limit.

\section{Virus Reduction to Achieve Drinking Water Quality}

The simulated mean enterovirus concentrations ranged from $7 \times 10^{-5}$ to $3 \mathrm{MPN} \mathrm{L}^{-1}$ in the Danube River and from $5 \times 10^{-7}$ to $120 \mathrm{MPN} \mathrm{L}^{-1}$ in the floodplain river in the four scenarios (Table 4). The simulated norovirus concentrations were as much as two magnitudes higher than the enterovirus concentrations in both rivers (Table 4). Currently, the 95th percentile-required reduction of enterovirus is $4.5 \log _{10}$ for the Danube River and

Table 3. Comparison of measured and simulated human-associated HF183 microbial source tracking marker and enterovirus concentrations in the Danube River and the floodplain river after calibration and verification with QMRAcatch.

\begin{tabular}{|c|c|c|c|c|c|c|c|c|c|c|c|c|}
\hline & \multicolumn{4}{|c|}{ Measured valuest } & \multicolumn{4}{|c|}{ Simulated values } & \multicolumn{4}{|c|}{$\log _{10}$ (measured/simulated) } \\
\hline & Mean & $\begin{array}{c}\text { 95th } \\
\text { percentile }\end{array}$ & $\alpha$ & $\beta$ & Mean & $\begin{array}{c}\text { 95th } \\
\text { percentile }\end{array}$ & $\alpha$ & $\beta$ & Mean & $\begin{array}{c}\text { 95th } \\
\text { percentile }\end{array}$ & $\alpha$ & $\beta$ \\
\hline & \multicolumn{2}{|c|}{$\mathrm{N} \mathrm{L}^{-1}$} & & & \multicolumn{2}{|c|}{$\mathrm{N} \mathrm{L}^{-1}$} & & & & & & \\
\hline $\begin{array}{l}\text { MST } \neq \text { marker in } \\
\text { Danube River, } 2012\end{array}$ & 14,000 & 51,000 & 0.41 & 47,000 & 8,500 & 32,400 & 0.49 & 18,000 & 0.22 & 0.20 & -0.08 & 0.42 \\
\hline $\begin{array}{l}\text { MST marker in } \\
\text { floodplain river, } 2012\end{array}$ & 1,100 & 3,700 & 1.00 & 5,300 & 1,700 & 6,400 & 0.54 & 3,200 & -0.19 & -0.24 & 0.27 & 0.22 \\
\hline $\begin{array}{l}\text { Enterovirus in } \\
\text { Danube River, } 2012\end{array}$ & 0.08 & 0.33 & 5.30 & 0.04 & 0.31 & 0.72 & 2.00 & 0.15 & -0.59 & -0.34 & 0.42 & -0.54 \\
\hline $\begin{array}{l}\text { MST marker in } \\
\text { Danube River, } 2013\end{array}$ & 9,900 & 19,000 & 4.30 & 2,300 & 16,700 & 35,000 & 3.00 & 5,600 & -0.23 & -0.27 & 0.16 & -0.39 \\
\hline $\begin{array}{l}\text { MST marker in } \\
\text { floodplain river, } 2013\end{array}$ & 2,200 & 7,900 & 0.63 & 8,900 & 1,990 & 8,300 & 0.39 & 5,200 & 0.04 & -0.02 & 0.21 & 0.23 \\
\hline $\begin{array}{l}\text { Enterovirus in } \\
\text { Danube River, } 2013\end{array}$ & 0.44 & 1.46 & n.a.§ & n.a. & 0.35 & 1.59 & n.a. & n.a. & 0.10 & -0.04 & n.a. & n.a. \\
\hline
\end{tabular}

†The parameters $\alpha$ and $\beta$ are dimensionless.

‡ MST, Microbial source tracking.

$\S$ Not available.

Table 4. Scenario results. Simulated enterovirus and norovirus concentrations in the Danube River and the floodplain river and the required level of reduction to achieve a drinking water infection risk of $\leq 1$ per 10,000 persons per year. $\dagger$

\begin{tabular}{|c|c|c|c|c|c|c|c|}
\hline & Unit & $\begin{array}{l}\text { Current } \\
\text { situation, } \\
\text { wet year }\end{array}$ & $\begin{array}{l}\text { 1. Low } \\
\text { pollution, } \\
\text { wet year }\end{array}$ & $\begin{array}{l}\text { 2. High } \\
\text { pollution, } \\
\text { wet year }\end{array}$ & $\begin{array}{c}\text { Current } \\
\text { situation, } \\
\text { dry year }\end{array}$ & $\begin{array}{l}\text { 3. Low } \\
\text { pollution, } \\
\text { dry year }\end{array}$ & $\begin{array}{l}\text { 4. High } \\
\text { pollution, } \\
\text { dry year }\end{array}$ \\
\hline Concentration in Danube & $\mathrm{N} \mathrm{L}^{-1}$ & & & & & & \\
\hline Enterovirus & & 0.59 & $7 \times 10^{-5}$ & 5.9 & 1.1 & $1 \times 10^{-4}$ & 11 \\
\hline Norovirus & & 33 & 0.003 & 330 & 51 & 0.005 & 500 \\
\hline Concentration in floodplain river & $\mathrm{N} \mathrm{L}^{-1}$ & & & & & & \\
\hline Enterovirus & & 0.1 & $8 \times 10^{-7}$ & 630 & 0.11 & 0.0 & 21 \\
\hline Norovirus & & 11 & $3 \times 10^{-4}$ & 720 & 14 & 0.0 & 56 \\
\hline Required reduction from Danube & $\log _{10}$ & & & & & & \\
\hline Enterovirus & & 4.3 & 1.6 & 5.4 & 4.5 & 2.1 & 5.7 \\
\hline Norovirus & & 6.6 & 4.1 & 7.7 & 6.6 & 4.3 & 8.2 \\
\hline Required reduction from floodplain river & $\log _{10}$ & & & & & & \\
\hline Enterovirus & & 3.6 & -0.4 & 7.7 & 3.5 & -0.9 & 6.2 \\
\hline Norovirus & & 5.5 & 1.1 & 7.8 & 5.7 & 0.9 & 7.1 \\
\hline Required reduction from floodplain & $\log _{10}$ & & & & & & \\
\hline Enterovirus & & n.a.‡ & n.a. & n.a. & 3.3 & no data & 5.8 \\
\hline Norovirus & & n.a. & n.a. & n.a. & 5.6 & no data & 5.9 \\
\hline Drinking water infection risk§ & $\mathrm{p}^{-1} \mathrm{y}^{-1}$ & & & & & & \\
\hline Enterovirus & & $8 \times 10^{-5}$ & $6 \times 10^{-5}$ & $7 \times 10^{-5}$ & $8 \times 10^{-5}$ & $4 \times 10^{-5}$ & $8 \times 10^{-5}$ \\
\hline Norovirus & & $8 \times 10^{-5}$ & $5 \times 10^{-5}$ & $7 \times 10^{-5}$ & $1 \times 10^{-4}$ & $5 \times 10^{-5}$ & $6 \times 10^{-5}$ \\
\hline
\end{tabular}

† Model variables were set as shown in Table 1. The criteria for the scenarios are shown in Table 2. Values are the 95th percentiles.

‡ Not available.

$\S$ The health-based target is $\leq 1 \times 10^{-4}$ infections person ${ }^{-1} \mathrm{yr}^{-1}$. 
$3.6 \log _{10}$ for the floodplain river; each of these values was roughly $2 \log _{10}$ more for norovirus (Table 4). According to the low- and high-pollution scenarios, the 95th percentile-required reduction of enterovirus for the Danube River ranges from 1.6 to 5.7 and from 0 to 7.7 for the floodplain river (Table 4). According to the same scenarios but for norovirus, the 95 th percentile reduction ranges from 4.1 to 8.2 and from 0.9 to 7.8 , respectively (Table 4 ).

The simulated target viral concentrations in the Danube River were found to be 20 to $70 \%$ lower in the wet year than in the dry year (Table 4). Viral concentrations are more diluted when higher discharges are released from the Danube. The simulated target viral concentrations in the floodplain river were found to be 0.05 - to 30 -fold higher in the wet than in the dry years because of the additional precipitation and runoff (Table 4). The calculated required viral reduction in wet and dry years differed by no less than $0.5 \log _{10}$ for the Danube River and by $1.5 \log _{10}$ for the floodplain river.

\section{Discussion}

Several frameworks, such as the WHO Water Safety Plan framework (WHO, 2009) and the EU Drinking Water Directive (EU, 1998), demand robust management of water resources to ensure a safe drinking water supply in the future. In support of this task, models such as QMRAcatch are needed to estimate the required sustainable protection measures and robust treatment targets in consideration of the sources and transport of fecal pollution in catchments used for drinking water supplies. QMRAcatch has been previously tested as a model for a riverbank infiltration site at the Danube River by Schijven et al. (2015), assuming the WWTP was the main pollution source in upstream areas. We have shown the successful extension of testing QMRAcatch to a river/floodplain system for the same section of the river by including additional potential human sources from the floodplain areas.

QMRAcatch was calibrated to the human fecal pollution emission patterns using human-associated HF183 MST marker concentrations determined for the Danube River and the floodplain river. We introduced a tiered approach based on calibration of QMRAcatch to measured concentrations of the HF183 MST marker for a dry year and a wet year followed by verification of the modeled enterovirus concentrations with measured values. Verification of enterovirus concentrations in the floodplain river for 2013 was limited because $100 \%$ of the values were nondetectable; however, they were verified in that the simulations also yielded enterovirus concentrations below the limit of detection $\left(<0.1 \mathrm{MPN} \mathrm{L}^{-1}\right)$.

The simulation tool is based on simplifications that can impose limitations on interpretation of the findings. For example, retention and release of TMVs that may attach to river sediments, groundwater exchange, and diffuse sources will be part of extending the model. These processes are indirectly included in the lumped mixing rates of the river. The successful prediction of $E$. coli in the Danube with the calibrated QMRAcatch model by human-associated genetic fecal markers for different time periods by Schijven et al. (2015) strongly supports the assumption that WWTPs are the dominant source. The occurrence of TMVs from human and animal fecal droppings is assumed to be homogenously distributed (i.e., the same at all points in the floodplain). However, higher densities of animal fecal droppings were observed in certain areas, such as the upstream section of the floodplain river. Also, if visitors practice open defecation, they will likely stay close to the hiking trails, which consist of a network of trails in the floodplain area. Compared with the animals, the homogeneous distribution of direct human pollution sources is thus better justified. Also, the process parameters describing the release and runoff within the floodplain area were very simple; that is, constant fractions were used (Schijven et al., 2015). Also, TMV concentrations were assumed to be homogeneously distributed in human feces, and a constant release rate over time was assumed. Up to now, only a few studies have investigated release rates from fecal droppings (Guber et al., 2015). The potential impact of environmental factors (e.g., duration of dry periods, air temperature, or the frequency of flooding) on these release rates remains largely unknown. In QMRAcatch, release is implemented as a single fraction. The uncertainties associated with some of the model variables (i.e., TMV concentrations of wastewater and fecal matter, fecal weight) were considered in QMRAcatch by drawing random numbers from statistical distributions within a Monte-Carlo framework instead of using constant values. In addition, some of the model variables were varied within reported ranges (Table 2).

The human-associated fecal MST marker performed successfully as an indicator in the studied river/floodplain environment. This was demonstrated by varying the false-positive MST marker concentrations in animal feces within the measured ranges. This resulted in variations of HF183 MST marker concentrations in the floodplain river of less than $8 \%$. To the best of our knowledge, this is the first demonstration of including quantitative fecal specificity and sensitivity HF183 MST marker performance data into the model. Inclusion of other fecal pollution sources and pathogens from potentially relevant animal sources (zoonotic pathogens; Stalder et al., 2011) will be introduced into the model in the future. A comprehensive model calibration will be attempted by including additional animal-associated MST markers, such as those from ruminant and boar fecal sources (Wuertz et al., 2011).

According to the model calibration, $4.5 \log _{10}$ of enterovirus and $6.6 \log _{10}$ of norovirus concentrations (95th percentiles) must be removed from water of the Danube River to achieve drinking water quality (Table 4). From the Danube and floodplain river water, viral concentrations are currently reduced by river bank filtration (RBF) and chlorination at the study site. The disinfection step by chlorination is designed to achieve a 4 $\log _{10}$ reduction according to the Austrian Codex Alimentarius (BMG, 2015). Currently, $2.6 \log _{10}$ would have to be achieved by RBF. According to Derx et al. (2013), several $\log _{10}$ more can be achieved by RBF in certain circumstances. They performed 3-dimensional virus transport simulations in fluvial aquifers using virus reduction rates from various reported field tracer experiments (Pang, 2009) and showed that the achieved viral reduction by $\mathrm{RBF}$ can range widely depending on the aquifer conditions. The actual treatment performance of RBF systems must therefore be carefully studied for every site.

A major objective of this study was to estimate sustainable reduction targets of selected viral pathogens for robust water safety management for the considered catchment. In the low pollution scenario, a $5 \log _{10}$ virus reduction at the WWTPs was 
considered. It was further assumed very unlikely that visitors practice open defecation in the floodplain. Only visitors coming from remote areas (excluding bikers) were considered to have a low viral prevalence. In contrast, in the high-pollution scenario, no wastewater treatment and a high chance that visitors practice open defecation in the floodplain were assumed. Although this is very unlikely to happen in the future, it is a useful scenario for investigating robust design criteria for the water supply treatment system. Based on this scenario, a robust design would be achieved with $8 \log _{10}$ virus reduction from the Danube and the floodplain river (Table 4). Combined RBF and chlorination should, in theory, be sufficient to ensure an adequate virus reduction even for this unlikely event. The actual achieved viral reduction during RBF, however, will have to be investigated in more detail. The low-pollution scenario showed that the potential for fecal pollution is currently higher from the Danube than from the floodplain river by 1 to $3 \log _{10}$ (Table 4). In the highpollution scenario, the potential for fecal pollution is higher in the floodplain river, but this is very unlikely to happen (Table 4). The low-contamination scenario shows great potential for the protection of drinking water catchments. As seen in this scenario, no further enterovirus reduction would be required in the floodplain river water. Interestingly, protection measures targeting both the WWTPs and direct pollution in the floodplain were shown to have similar potentials for improving the microbial water quality at the study site. Such measures could comprise, for example, additional ozone and UV treatments of wastewater from WWTPs upstream in the Danube River, which reportedly achieved at least 2 and $4 \log _{10}$ reductions, respectively (WHO, 2011). The placement of public toilets and signs may help in preventing pollution from visitors in the flood plain. This further supports the philosophy of targeting the source of pollution in the catchment for protecting drinking water resources (WHO, 2011). The simulations further demonstrated that in wet and dry years, the required virus reduction hardly differs between the low-pollution scenario and the current situation. The high-pollution scenario showed that from 0.7 to $1.5 \log _{10}$ higher virus reductions from floodplain river water are required in wet years because of more precipitation and runoff. These results can help decision-makers to better plan the design of water supply systems in the future. Even though current water treatment regulations in different countries worldwide provide important information, they do not provide specific guidance; for example, in the United States and Canada, a virus reduction of at least $4 \log _{10}$ is required from surface water before it is considered safe for drinking (Health Canada, 2011; USEPA, 2012), whereas the WHO guidelines recognize that water treatment requirements will differ for different sites (WHO, 2011). QMRAcatch is freely accessible and can be applied at locations where one or more of the described compartments and pollution sources must be addressed.

\section{Conclusions}

QMRAcatch, a free-access catchment model for simulating microbial quality of surface water, was successfully applied for a river/floodplain system of the Danube River in Austria. A human-associated HF183 MST marker proved to be very useful for setting hydrological and pollution source-associated variables, such as mixing degree, number of overflows, overflow water concentration, HF183 MST marker release rate, and $P_{\text {hum }}$, enabling prediction of pathogen concentrations using QMRAcatch. The model can be used to demonstrate that 4.5 $\log _{10}$ and $6.6 \log _{10}$ (95th percentiles) reductions in enterovirus and norovirus, respectively, must be achieved by the current treatment barriers (RBF and disinfection). The simulations showed that, with further measures for preventing fecal emissions from WWTPs and within the floodplain area, no further reduction of enterovirus from the floodplain river would be required to achieve drinking water quality according to the health-based target set. These results indicate the great potential of targeting fecal pollution sources in the catchment for minimizing the fecal burden on water resources. This information can be used to support the future design of robust water supply systems and thus has implications for water suppliers and authorities.

\section{Acknowledgments}

This work was supported by the Austrian Science Fund (FWF) as part of the Vienna Doctoral Programme on Water Resource Systems (W1219-N22), the FWF projects P22309-B20 and P23900-B22, and the research project Groundwater Resource Systems Vienna as part of the (New) Danube-Lower Lobau Network Project (LE07-13) in cooperation with Vienna Waterworks. We would like to thank the via donau-Österreichische Wasserstrassen-Gesellschaft mbH for providing the discharge and temperature data of the Danube River. This is a joint investigation of the Interuniversity Cooperation Centre for Water \& Health (www.waterandhealth.at).

\section{References}

Anonymous. 2014. Hydrographisches Jahrbuch von Österreich 2012. The Austrian Federal Ministry of Agriculture, Forestry, Environment and Water Management (BMLFUW), Vienna, Austria.

Arnberger, A. 2006. Recreation use of urban forests: An inter-area comparison. Urban For. Urban Green. 4:135-144. doi:10.1016/j.ufug.2006.01.004

Arnberger, A., F. Frey-Roos, R. Eder, G. Muralt, U. Nopp-Mayr, H. Tomek, and M. Zohmann. 2009. Ecological and social carrying capacities for peri-urban biosphere resources. Man \& Biosphere-Programme of the Academy of Science 135. Austrian Academy of Science, Vienna, Austria.

Atmar, R.L., A.R. Opekun, M.A. Gilger, M.K. Estes, S.E. Crawford, F.H. Neill, and D.Y. Graham. 2008. Norwalk virus shedding after experimental human infection. Emerg. Infect. Dis. 14(10):1553-1557. doi:10.3201/ eid 1410.080117

Benham, B.L., C. Baffaut, R.W. Zeckoski, K.R. Mankin, Y.A. Pachepsky, A.A. Sadeghi, K.M. Brannan, M.L. Soupir, and M.J. Habersack. 2006. Modeling bacteria fate and transport in watersheds to support TMDLs. Trans. ASABE 49(4):987-1002. doi:10.13031/2013.21739

Blöschl, G., W. Schöner, H. Kroiß, A. P. Blaschke, R. Böhm, K. Haslinger, N. Kreuzinger, R. Merz, J. Parajka, J. L. Salinas, A. Viglione. 2011. Anpassungsstrategien an den Klimawandel für Österreichs WasserwirtschaftZiele und Schlussfolgerungen der Studie für Bund und Länder. Österreichische Wasser- und Abfallwirtschaft 63(1-2):1-10.

Bundesministerium für Gesundheit (BMG). 2015. Österreichisches Lebensmittelbuch. 4th edition, codex chapter/B1/drinking water. https://www. verbrauchergesundheit.gv.at/lebensmittel/buch/codex (accessed 8 Mar. 2016)

Chang, S.L., G. Berg, K.A. Busch, R.E. Stevenson, N.A. Clarke, and P.W. Kabler. 1958. Application of the "most probable number" method for estimating concentrations of animal viruses by the tissue culture technique. Virology 6(1):27-42. doi:10.1016/0042-6822(58)90057-6

Chin, D.A., D. Sakura-Lemessy, D.D. Bosch, and P.A. Gay. 2009. Watershedscale fate and transport of bacteria. Trans. ASABE 52(1):145-154. doi: $10.13031 / 2013.25955$

Cool, G., M.J. Rodriguez, C. Bouchard, P. Levallois, and F. Joerin. 2010. Evaluation of the vulnerability to contamination of drinking water systems for rural regions in Quebec, Canada. J. Environ. Plann. Manage. 53(5):615-638. doi:10.1080/09640561003727128

Derx, J., A.P. Blaschke, A.H. Farnleitner, L. Pang, G. Blöschl, and J.F. Schijven. 2013. Effects of fluctuations in river water level on virus removal by bank filtration and aquifer passage: A scenario analysis. J. Contam. Hydrol. 147:34-44. doi:10.1016/j.jconhyd.2013.01.001 
Eder, R., and A. Arnberger. 2012. The influence of place attachment and experience use history on perceived depreciative visitor behavior and crowding in an urban national park. Environ. Manage. 50:566-580. doi:10.1007/ s00267-012-9912-8

Encyclopedia Brittanica. 2015. Feces. www.britannica.com/EBchecked/topic/203293/feces (accessed 13 May 2015).

EU. 1998. Council directive 98/83/EC of 3 Nov. 1998 on the quality of water intended for human consumption. FAO, Geneva, Switzerland.

EU. 2006. Directive 2006/7/EC of the European Parliament and of the Council of $15 \mathrm{Feb} .2006$ concerning the management of bathing water quality and repealing Directive 76/160/EEC as amended by Regulation 596/2009/ EC. FAO, Geneva, Switzerland.

Farnleitner, A.H., G. Ryzinska-Paier, G.H. Reischer, M.M. Burtscher, S. Knetsch, S. Rudnicki, T. Dirnböck, G. Kuschnig, R.L. Mach, and R. Sommer. 2010. Escherichia coli and enterococci are sensitive and reliable indicators for human, livestock, and wild life faecal pollution in alpine mountainous water resources. J. Appl. Microbiol. 109(5):1599-1608.

Farnleitner, A., J. Derx, C. Frick, P. Reiner, D. Savio, C. Zoufal-Hruza, G. Reischer, R. Mach, A. Kirschner, W. Zoufal, T. Nadiotis-Tsaka, R. Sommer, and A.P. Blaschke. 2014. Water connection (New) Danube. Lower Lobau (Nationalpark Donauauen), Water quality report for microbiology/water hygiene. Municipal Department MA45. Vienna Waters, Vienna, Austria.

Gabriel, H., A.P. Blaschke, R. Taschke, and E. Mayr. 2014. Water connection (New) Danube-Lower Lobau (Nationalpark Donauauen). Water quantity report for surface water, Municipal Department MA45. Vienna Waters, Vienna, Austria.

Green, H.C., R.A. Haugland, M. Varma, H.T. Millen, M.A. Borchardt, K.G. Field, W.A. Walters, R. Knight, M. Sivaganesan, C.A. Kelty, and O.C. Shanks. 2014. Improved HF 183 quantitative real-time PCR assay for characterization of human fecal pollution in ambient surface water samples. Appl. Environ. Microbiol. 80:3086-3094. doi:10.1128/AEM.04137-13

Guber, A.K., J. Fry, R.L. Ives, and J.B. Rose. 2015. Escherichia coli survival in, and release from, white-tailed deer feces. Appl. Environ. Microbiol. 81(3):1168-1176. doi:10.1128/AEM.03295-14

Hahn, S., S. Bauer, and M. Klaassen. 2007. Estimating the contribution of carnivorous waterbirds to nutrient loading in freshwater habitats. Freshwater Biol. 52(12):2421-2433. doi:10.1111/j.1365-2427.2007.01838.x

Health Canada. 2011. Guidelines for Canadian drinking water quality: Guideline technical document, Ottawa, Ontario. www.hc-sc.gc.ca/ewh-semt/ pubs/water-eau/sum_guide-res_recom/index-eng.php (accessed 8 Mar. 2016).

HRWM. 2011. Joint meeting of the International Water Association's 16th Health Related Water Microbiology Symposium and 15th Diffuse Contamination Conference held jointly at Rotorua, New Zealand on Sunday 18th September 2011.

Katayama, H., E. Haramoto, K. Oguma, H. Yamashita, A. Tajima, H. Nakajima, and S. Ohgaki. 2008. One-year monthly quantitative survey of noroviruses, enteroviruses, and adenoviruses in wastewater collected from six plants in Japan. Water Res. 42(6-7):1441-1448. doi:10.1016/j.watres.2007.10.029

Lodder, W.J., and A.M. de Roda Husman. 2005. Presence of noroviruses and other enteric viruses in sewage and surface waters in The Netherlands. Appl. Environ. Microbiol. 71(3):1453-1461. doi:10.1128/ AEM.71.3.1453-1461.2005

Manning, R. 1891. On the flow of water in open channels and pipes. Trans. Inst. Civil Eng. Ireland 20:161-207.

McBride, G.B., R. Stott, D. Papps, C. Palliser, G. Jenner, G. Macdonald. 2012. Estimating health risks to water users: Marrying hydrodynamic models and risk models. Water Practice Technol. 7:1-8.

Melnick, J.L., and V. Rennick. 1980. Infectivity liters of enterovirus as found in human stools. J. Med. Virol. 5(3):205-220. doi:10.1002/jmv.1890050305

Merz, R., and G. Blöschl. 2009. A regional analysis of event runoff coefficients with respect to climate and catchment characteristics in Austria. Water Res. Res. 45:W01405. doi:10.1029/2008WR007163

Pang, L. 2009. Microbial removal rates in subsurface media estimated from published studies of field experiments and large intact soil cores. J. Environ. Qual. 38:1531-1559. doi:10.2134/jeq2008.0379

Parz-Gollner, R. 2006. Zur Situation der Kormoranschlafplätze im Nationalpark Donau-Auen (NÖ)- Auswirkungen der Uferrückbauten im Bereich des Schlafplatzes Trunhaufen. University of Applied Science, Vienna, Austria.
Reischer, G.H., J.M. Haider, R. Sommer, H. Stadler, K.M. Keiblinger, R. Hornek, W. Zerobin, R.L. Mach, and A.H. Farnleitner. 2008. Quantitative microbial faecal source tracking with sampling guided by hydrological catchment dynamics. Environ. Microbiol. 10(10):2598-2608. doi:10.1111/j.1462-2920.2008.01682.x

Schijven, J., M. Bouwknegt, A.M. de Roda Husman, S. Rutjes, B. Sudre, J.E. Suk, and J.C. Semenza. 2013. A decision support tool to compare waterborne and foodborne infection and/or illness risks associated with climate change. Risk Anal. 33(12):2154-2167. doi:10.1111/risa.12077

Schijven, J.F., J. Derx, A.M. de Roda Husman, A.P. Blaschke, and A.H. Farnleitner. 2015. QMRAcatch: Microbial quality simulation of water resources including infection risk assessment. J. Environ. Qual. 44(5):1491-1502. doi:10.2134/jeq2015.01.0048

Schmidt, M., K. Sommer, W.U. Kriebitzsch, H. Ellenberg, and G. von Oheimb. 2004. Dispersal of vascular plants by game in northern Germany. Part I: Roe deer (Capreolus capreolus) and wild boar (Sus scrofa). Eur. J. For. Res. 123(2):167-176. doi:10.1007/s10342-004-0029-3

Schulze, K., M. Hunger, and P. Döll. 2005. Simulating river flow velocity on global scale. Adv. Geosci. 5:133-136. doi:10.5194/adgeo-5-133-2005

Sokolova, E., S.R. Petterson, D.D. Olaf, F. Nystrom, P.E. Lindgren, and T.J.R. Pettersson. 2015. Microbial risk assessment of drinking water based on hydrodynamic modelling of pathogen concentrations in source water. Sci. Total Environ. 526:177-186. doi:10.1016/j.scitotenv.2015.04.040

Stalder, G.L., A. Farnleitner, R. Sommer, C. Beiglböck, and C. Walzer. 2011. Hazard and risk based concepts for evaluating the microbial water quality: Part 2. Vet. Med.Austria 98:54-65.

Taschke, R., A.P. Blaschke, H. Gabriel, and E. Mayr. 2014. Water connection (New) Danube-Lower Lobau (Nationalpark Donauauen). Water quantity report for groundwater, Municipal Department MA45. Vienna Waters, Vienna, Austria.

Teunis, P.F.M., C.L. Moe, P. Liu, S.E. Miller, L. Lindesmith, R.S. Baric, J. Le Pendu, and R.L. Calderon. 2008. Norwalk virus: How infectious is it? J. Med. Virol. 80(8):1468-1476. doi:10.1002/jmv.21237

USEPA. 2012. 2012 edition of the drinking water standards and health advisories. EPA 822-S-12-001. Office of Water, USEPA, Washington, DC.

via donau. 1997. Die kennzeichnenden Wasserstande der österreichischen Donau, KWD 1996. Vienna, Austria.

Vierheilig, J., C. Frick, R. Mayer, A.K.T. Kirschner, G.H. Reischer, J. Derx, R.L. Mach, R. Sommer, and A.H. Farnleitner. 2013. Clostridium perfringens is not a suitable indicator for faecal pollution from ruminant wildlife but is associated with non-herbivorous excreta and human sewage. Appl. Environ. Microbiol. 79(16):5089-5092. doi:10.1128/AEM.01396-13

von Oheimb, G., M. Schmidt, W.U. Kriebitzsch, and H. Ellenberg. 2005. Dispersal of vascular plants by game in northern Germany. Part II: Red deer (Cervus elaphus). Eur. J. For. Res. 124(1):55-65. doi:10.1007/ s10342-005-0053-y

Walter, R., and S. Rüdiger. 1981. Ein Zweistufenverfahren zur Virusanreicherung aus Lösungen mit geringem Virustiter. J. Hyg. Epidemiol. Microbiol. Immunol. 25:71-81

World Health Organization (WHO). 2009. Water safety plan manual (WSP manual): Step-by-step risk management for drinking-water suppliers. WHO, International Water Association, Geneva, Switzerland.

World Health Organization (WHO). 2011. Guidelines for drinking-water quality, 4th ed. WHO, International Water Association, Geneva, Switzerland.

Wu, J., P. Rees, S. Storrer, K. Alderisio, and S. Dorner. 2009. Fate and transport modeling of potential pathogens: The contribution from sediments. J. Am. Water Resour. Assoc. 45(1):35-44.

Wuertz, S., D. Wang, G. Reischer, and A.H. Farnleitner. 2011. Microbial source tracking: Methods, applications and case studies. In: C. Hagedorn, J. Haarwood, A. Blanch, editors, Library independent bacterial methods, Springer, New York. p. 61-112.

Zhang, X., W. Hongyu, D. Shujun, X. Wang, X. Chen, Y. Wo, L. Wang, D. Huang, W. Liu, and W. Cao. 2013. Prevalence of enteroviruses in children with and without hand, foot, and mouth disease in China. BMC Infect. Dis. 13:606. doi:10.1186/1471-2334-13-606 